\title{
SPATIAL DISTRIBUTION OF PRECIPITATION AND EVAPOTRANSPIRATION ESTIMATES FROM WORLDCLIM AND CHELSA DATASETS: IMPROVING LONG-TERM WATER BALANCE AT THE WATERSHED-SCALE IN THE URABÁ REGION OF COLOMBIA
}

\author{
BREINER BASTIDAS OSEJO, TERESITA BETANCUR VARGAS \& JOHN ALEJANDRO MARTINEZ \\ Grupo de Ingeniería y Gestión Ambiental (GIGA), Facultad de Ingeniería, Universidad de Antioquia, Medellín, \\ Colombia.
}

\begin{abstract}
In this paper, we have evaluated high-resolution spatial gridded climate data from two long-term global datasets, WorldClim V.2.0 and Chelsa V.1.2, in representing variables like precipitation and temperature for the Urabá region of Colombia. Additionally, climate variables from these datasets have been used to estimate evapotranspiration using traditional methods such as the Turc, Hargreaves and Thornthwaite equations. Finally, the results of long-term spatial climate characterization are used to apply the water balance equation in the surface at the watershed scale, to obtain the long-term average streamflow of the main streams of the Urabá region; these streamflows are compared with the observations of hydrological stations. We find that the WorldClim and Chelsa rainfall estimates show average differences between 20\% and 23\% compared to the average annual rainfall in the area from in situ measurements. Both datasets are able to reproduce the rainfall average annual cycle, although Chelsa shows a slightly better performance. Regarding near surface air temperature we find that WorldClim shows a good performance, while Chelsa significantly underestimates the average temperature. Finally, we found that the Hargreaves and Thornthwaite methods lead to the best performance in estimating streamflow from the water balance, probably because details of the seasonal behavior of variables like temperature and radiation are explicitly included in these methods. On the other hand, the Turc method yields larger estimates of evapotranspiration and therefore the corresponding derived streamflows are lower than those observed. The good performance of the WorldClim and Chelsa datasets in representing variables like precipitation, temperature, and the derived watershed-scale streamflow, suggest that these long-term global climate datasets can be used to study the spatial distribution of important hydrological variables in the Urabá region of Colombia, and consequently the estimation of average streamflows through the method of the long-term water balance. Keywords: Chelsa 1.2, long-term water balance, performance, streamflow, WorldClim V.2.0.
\end{abstract}

\section{INTRODUCTION}

The hydroclimatological spatial behavior at the watershed-scale is of great importance for the understanding of surface hydrological processes at different time scales, which in turn interact with atmospheric processes to generate feedback cycles [1]. The ideal way to obtain an approximation to this spatial behavior is from the direct observations of hydroclimatological variables of interest, however this isn't always possible; because the spatial distribution of the monitoring stations, their periodicity and quality of the records aren't always meet the desirable conditions [1]-[3], so it's useful to use auxiliary variables that help fill gaps in information and improve understanding of the spatial pattern of variables such as precipitation, temperature, evaporation and radiation among others, all these variables finally they intervene in the water balance in the atmosphere and surface.

Several auxiliary variables have been used to characterize the hydroclimatological behavior of different region, among these variables are mainly information from remote sensors such as; TRMM, GPM and MOD16, and climate reanalysis datasets such as; ERA-Interim, ERA5, GPCC, Chelsa and WorldClim [1]-[7]. 
In this paper, we explore the use of two datasets: WorldClim V.2.0 [4] and Chelsa V.1.2 [5], which provide spatial gridded data of principal hydroclimatological variables at a high spatial resolution ( $1 \mathrm{~km}^{2}$ of pixel) and for long-term conditions (climatological scale), in turn, several evapotranspiration estimation methods are evaluated and their effect in the long-term water balance, which is useful for the spatial estimation of average streamflows in watershed with limited and insufficient monitoring networks.

\section{STUDY AREA}

The study area is an extension of 2,930 $\mathrm{km}^{2}$ on the Urabá Banana Axis (Colombia), specifically covers the León, Grande, Guadualito, Turbo and Currulao river watersheds. The hydroclimatological analysis domain extends from $77.13 \mathrm{~W}$ to $76.21 \mathrm{~W}$ and from $7.275 \mathrm{~N}$ to $8.616 \mathrm{~N}$, this domain allows to include boundary conditions around the watersheds of interest. The mentioned watersheds and analysis domain are shown in Fig. 1. The adequate estimation of the average streamflows in the mentioned rivers is important because in this zone the use of water is intensive and the watersheds show high vulnerability to events of climatic variability: droughts and floods [8], [11].

\section{DATA AND METHODS}

The data used in this paper are of two types: climate observations on land; time series of hydrometeorological stations of the national monitoring network of Colombia, and highresolution spatial gridded climate data from long-term global datasets. Another important data source is the topography of the study area, a fundamental aspect for estimating the longterm water balance.

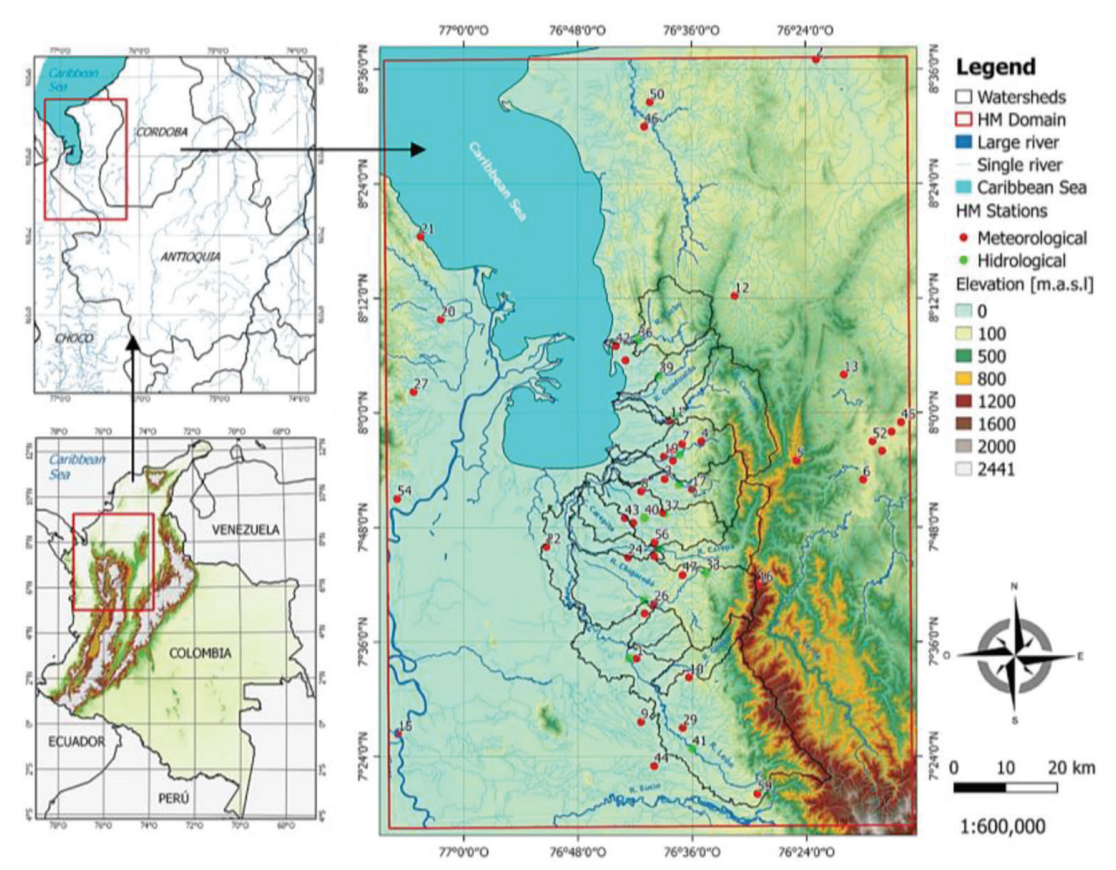

Figure 1: Study area, watersheds, topography (Digital Terrain Model) and hydro meteorological monitoring stations. 


\subsection{Topography and hydrometeorological stations}

The study area topography was defined from the Digital Terrain Model (DTM) obtained from the ALOS satellite, which collects terrestrial images through its PALSAR sensor (Phased Array Type L-band Synthetic Aperture Radar), this information can be downloaded free on the website [9], and has a resolution of $12.5 \mathrm{~m}$ x $12.5 \mathrm{~m}$ pixel size. Figure 1 shows the used DTM, which was previously corrected using the Watershed Delineation Plugin from MapWindow Software to eliminate flat zones and sinkhole.

The hydrometeorological information was requested to the Colombia Institute of Hydrology, Meteorology and Environmental Studies (IDEAM), the temporal resolution of the requested variables is daily scale and updated to December 2017 (where possible). Variables of total precipitation, average near surface air temperature and average streamflow of the main rivers in study area were requested. Table 1 shows the general characteristics of the identified hydrometeorological stations (meteorological: M, hydrological: $\mathrm{H}$ ) in the study area, and Fig. 1 shown your geographical location.

Table 1: Available meteorological stations in study area.

\begin{tabular}{|c|c|c|c|c|c|c|c|c|}
\hline ID & Name & $\begin{array}{c}\text { Station } \\
\text { Kind }\end{array}$ & ID & Name & $\begin{array}{c}\text { Station } \\
\text { Kind }\end{array}$ & ID & Name & $\begin{array}{c}\text { Station } \\
\text { Kind }\end{array}$ \\
\hline 1 & Barranquillita & M & 21 & Titumate & $\mathrm{M}$ & 41 & Villarteaga & $\mathrm{H}$ \\
\hline 2 & Carmelo El & M & 22 & Tormento El & M & 42 & Apto Gonzalo & M \\
\hline 3 & Casco El & M & 23 & Toscana La & M & 43 & $\begin{array}{l}\text { Apto Los } \\
\text { Cedros }\end{array}$ & M \\
\hline 4 & $\begin{array}{l}\text { Choromando } \\
\text { Hda }\end{array}$ & M & 24 & Trigana & M & 44 & Bajira & M \\
\hline 5 & Cielo El & M & 25 & Tucura & M & 45 & Campo Bello & M \\
\hline 6 & Despensa La & M & 26 & Tulenapa & M & 46 & Caribia & M \\
\hline 7 & Eupol & M & 27 & Unguia & M & 47 & Cerrazon La & M \\
\hline 8 & Lorena La & M & 28 & Urra 1 & M & 48 & Despensa La & M \\
\hline 9 & $\begin{array}{l}\text { Nuevo } \\
\text { Oriente }\end{array}$ & M & 29 & Villa Arteaga & M & 49 & $\begin{array}{l}\text { Idema- } \\
\text { Montecristo }\end{array}$ & M \\
\hline 10 & Palmera La & M & 30 & Apartado & $\mathrm{H}$ & 50 & Mellito El & M \\
\hline 11 & Prado Mar & M & 31 & Barranquillita & $\mathrm{H}$ & 51 & Palmera La & M \\
\hline 12 & Pueblo Bello & M & 32 & Carepa & $\mathrm{H}$ & 52 & Pto Nuevo & M \\
\hline 13 & Quimari & M & 33 & Cerrazon La & $\mathrm{H}$ & 53 & Riogrande & M \\
\hline 14 & Riogrande & M & 34 & Chigorodo & $\mathrm{H}$ & 54 & Sautata & M \\
\hline 15 & Riosucio & M & 35 & Currulao & $\mathrm{H}$ & 55 & Tucura & M \\
\hline 16 & Saiza & M & 36 & Dos El & $\mathrm{H}$ & 56 & Tulenapa & M \\
\hline 17 & $\begin{array}{l}\text { San Jose } \\
\text { Apartado }\end{array}$ & M & 37 & Pte Carretera & $\mathrm{H}$ & 57 & Turbo & M \\
\hline 18 & Sta Isabel & M & 38 & Riogrande & $\mathrm{H}$ & 58 & Uniban & M \\
\hline 19 & Sta Martha & M & 39 & Tres El & $\mathrm{H}$ & 59 & Villarteaga & M \\
\hline 20 & Tanela & M & 40 & Victoria La & $\mathrm{H}$ & & & \\
\hline
\end{tabular}




\subsection{High-resolution spatial gridded climate data}

The high-resolution spatial gridded climate data used for study area are obtained from two longterm global climate datasets: WorldClim V.2.0 and Chelsea V.1.2, which are described below.

\subsubsection{The Global Climate Data - WorldClim version 2.0}

Is a global dataset that provides spatial information of climate variables on a monthly scale: total precipitation, average, maximum and minimum temperature, vapour pressure, incident solar radiation and wind speed; for a 30 years' reference period comprised between 1970 and 2000. The climatology data observed in WorldClim have been obtained from rigorous interpolations at 30 arc-seconds spatial resolution (approximately $1 \mathrm{~km}^{2}$ ) of observations in situ (hydro meteorological stations) of various programs, entities and data sources, such as: Global Historical Climatology Network - GHCN, World Meteorological Organization WMO, International Center for Tropical Agriculture - CIAT, among many others [4].

The stations used vary between 9,000 and 60,000 depending on the interpolation site, the interpolation is done by a thin plate spline considering covariance with other predictor variables such as topography, distance to the coast and satellite data (e.g. MODIS). The interpolation of the climate variables is done in 23 regions, varying the size according to the available stations density, finally the WorldClim data are validated by global cross validation and the results obtained for version 2.0 are: 0.99 for temperature, 0.86 for precipitation and 0.76 for wind speed [4].

\subsubsection{The climatologies at High Resolution for The Earth's Land Surface Areas - Chelsa version 1.2}

For the land areas currently hosted by the Swiss Federal Institute, Snow and Landscape Research - WSL, and which has been developed in collaboration with the Institute of Geography of the University of Hamburg, is a global dataset that provides spatial information of climate variables on a monthly scale: total precipitation, average, maximum and minimum temperature, for a 35 years' reference period comprised between 1979 and 2013. The available data of climatology observed in Chelsa have been obtained from downscaling process of the temperature and precipitation outputs of the global circulation model and reanalysis ERA - Interim, at 30 arc-seconds spatial resolution (approximately $1 \mathrm{~km}^{2}$ ) [5].

For the temperature applies a statistical downscaling, while for rainfall a quasi-mechanistical statistical of the ERA-Interim model, including predictive variables such as topography, winds and thickness of the ABL, finally a series of bias corrections are made with the GPCC and GHCN stations and validation using a series of independent stations [5].

The spatial monthly information of total precipitation and average temperature of both datasets (WorldClim and Chelsa) allows generating annual average cycles of theses variables, and comparing them with the cycles generated from the observations of the hydrometeorological stations, and evaluating their performance to reproduce the local and regional climatology at watershed-scale, particularly for the study area of the Urabá Banana Axis (Colombia).

\subsection{Method for estimating the spatial distribution of precipitation}

The spatial distribution of precipitation is estimated using the kriging geostatistical interpolation, particularly the kriging with external drift (KED), which has been widely applied in the spatial interpolation of climate variables [3], [10]-[12]. In this study the KED method is 
applied to incorporate auxiliary variables (WorldClim and Chelsa precipitation gridded data) that allow to refine the spatial distribution of the climate variables of interest.

To interpolate the gridded precipitation fields, 37 of the 41 daily rainfall records obtained for the study area have been used, the four (4) records discarded due to a low record length (less than 10 years) and/or a large amount of missing data. For the KED method a theoretical semivariogram model type spherical nugget has been adjusted and the interpolation has been made at a pixel size of $100 \mathrm{~m}$.

\subsection{Methods for estimating the spatial distribution of evapotranspiration}

The actual evapotranspiration is required to the long-term water balance application, in this study we have spatially estimated this variable using four traditional methods: Cenicafé (local method for Colombia), Turc, Hargreaves, Thornthwaite and Budyko; the latter used to convert potential evapotranspiration (PET) to actual evapotranspiration (AET) in function of available precipitation.

The Budyko method is based on a mass balance to quantify the actual evapotranspiration depending on available water defined by the precipitation and the phase change potential defined by the potential evapotranspiration [13].

The Cenicafé method allows calculating the potential evapotranspiration (PET) in a very simple way, because it only depends on the terrain elevation, it's applicable only for Colombia region, because it was obtained as a result of a regression elaborated by Cenicafé (Colombia National Center for Coffee Research) between the evapotranspiration values obtained by applying the Penman-Monteith method to climate stations data of Colombia and the terrain elevation above the sea level [14]. The main disadvantage of this method is that the estimation depends on a static parameter (terrain elevation). In this paper the Cenicafé method is applied considering the digital terrain model (DTM) described above.

The Turc method estimates the actual evapotranspiration (AET) from a mass balance based on simple meteorological elements such as average temperature and precipitation in a watershed and applied to long-term measures [15].

The Thornthwaite method is applied on a monthly scale and gives an estimate of the monthly potential evapotranspiration (PET) as a function of the monthly average temperature, is based on the numerous experiments carried out with lysimeters [16]. In this paper Thornthwaite method is applied for each month of the annual cycle and later added to obtain the annual PET.

The Hargreaves method is one of the best methods to apply when we have scarce information, especially because it explicitly included one of the main variables related to the evapotranspiration physics, which is incident solar radiation. The Hargreaves method evaluates the potential evapotranspiration (PET) as a function of the incident solar radiation and the average temperature [17]. In this paper Hargreaves method has been applied on a monthly scale for the average annual cycle of average temperature and incident solar radiation and later added to obtain the annual PET.

\section{RESULT AND DISCUSSION}

\subsection{Hydroclimatological behavior in the study area}

The main hydroclimatological variables analysed in this paper for the study area were: the total precipitation, average streamflow and average near surface air temperature. In the study 
area, the rainfall shows a clear unimodal cycle, presenting a period of low rainfall between January and March, a period of high rainfall between May and November, and transition periods in April and December. Regarding average streamflows in the main rivers in the zone, these also have a unimodal cycle strongly related to rainfall, especially in the upper areas of the watersheds of interest. Figure 2 shows the annual cycles of rainfall and the average streamflow of some representative areas, such as the León river basin (Villa Arteaga Station) and the Currulao river watershed (Currulao and Prado Mar stations). The cycles are accompanied by the monthly statistical average errors.

\subsection{Representativeness of high-resolution spatial gridded climate data in study area}

Using the gridded climate data of WorldClim and Chelsa, the precipitation and average temperature annual cycles were extracted in each one of the geographic points that represent the hydrometeorological stations of the IDEAM, with this, the observed annual cycles (IDEAM Stations) and annual cycles from WorldClim and Chelsa are compared to evaluate the representativeness of these gridded climate data. Figure 3 shows rainfall and average temperature annual cycles compared for a couple stations, between observed data (stations) and WorldClim and Chelsa data.

Regarding precipitation, we found that both Chelsa and WorldClim adequately reproduce the annual cycle of the stations, although Chelsa shows a slightly better performance in terms of the correlation of the annual cycle, but at the same time has a slightly greater bias compared to the magnitudes of monthly and annual precipitation.
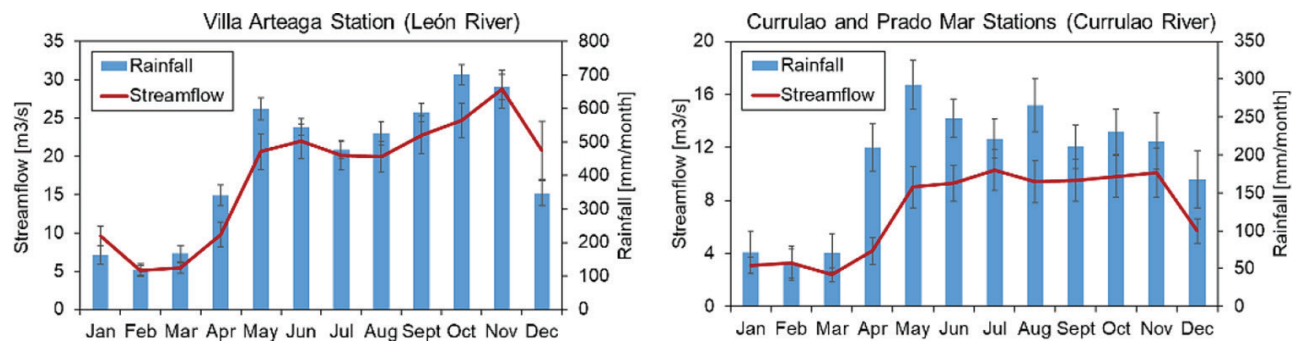

Figure 2: Rainfall-Runoff relationship in the study area described by the annual cycles of streamflow and precipitation of the IDEAM's stations: (left) León river basin, and (right) Currulao river watershed.
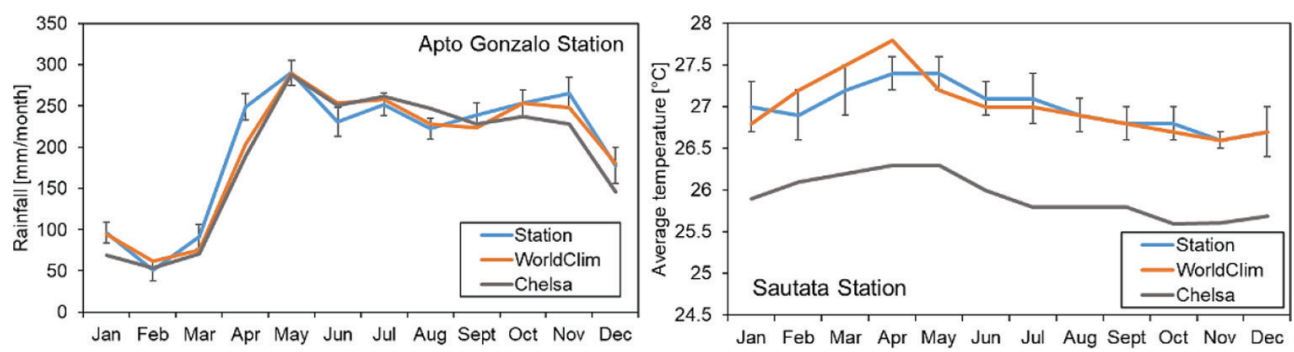

Figure 3: Comparison between annual cycles of rainfall (left) and of average temperature (right) of stations (blue line), WorldClim data (orange line) and Chelsa data (grey line) for a couple stations in the study area. 
Regarding average temperature, we find that Chelsa significantly underestimates the magnitude of the average monthly temperature, unlike with WorldClim, which has a lower bias and closer to the behavior of the data observed in the stations. The differences exhibited by Chelsa are order of 1 to $1.5^{\circ} \mathrm{C}$, while the differences exhibited by WorldClim are order of $0.5^{\circ} \mathrm{C}$ maximum. Seasonality (annual cycle) is reproduced approximately well by both datasets, without presenting significant differences between them. The lower performance of Chelsa with respect to the observed average temperature data, can be caused the temperature downscaling process from the reanalysis of ERA-Interm model, and although corrections are made for bias with respect to stations on the global scale, in the tropics, the reanalysis data can have various uncertainties that can continue to be preserved when these are escalated and affect the magnitude of variables such as temperature.

The evaluation of the representativeness of the WorldClim and Chelsa gridded climate data with respect to the observed stations data of the study area is numerically summarized in Tables 2 and 3 for the precipitation and average temperature, respectively. For the presented numerical evaluation, the following metrics are used: RMSE (root of the mean square error) of the annual cycles, Pearson correlation coefficient between the annual cycles and percentage bias between the annual aggregate values.

Table 2: Statistical summarize of metrics to evaluate the performance of the WorldClim and Chelsa precipitation data with respect to the stations precipitation data.

\begin{tabular}{|c|c|c|c|c|c|c|}
\hline \multirow[b]{2}{*}{$\begin{array}{l}\text { Summarize of } \\
\text { metric }\end{array}$} & \multicolumn{2}{|c|}{$\begin{array}{c}\text { RMSE [mm/ } \\
\text { month] }\end{array}$} & \multicolumn{2}{|c|}{$\begin{array}{c}\text { Bias [\%] Annual } \\
\text { Rainfall }\end{array}$} & \multicolumn{2}{|c|}{$\begin{array}{c}\text { Pearson Corr. - Annual } \\
\text { Cycle }\end{array}$} \\
\hline & $\begin{array}{l}\text { World- } \\
\text { Clim }\end{array}$ & Chelsa & $\begin{array}{l}\text { World- } \\
\text { Clim }\end{array}$ & Chelsa & $\begin{array}{l}\text { World- } \\
\text { Clim }\end{array}$ & Chelsa \\
\hline Number of stations & 40 & 40 & 40 & 40 & 40 & 40 \\
\hline Maximum & 169 & 238 & $50 \%$ & $65 \%$ & 0.99 & 0.99 \\
\hline Minimum & 17 & 15 & $-39 \%$ & $-48 \%$ & 0.15 & 0.84 \\
\hline Absolute Mean & 64 & 59 & $20 \%$ & $23 \%$ & 0.89 & 0.96 \\
\hline
\end{tabular}

Table 3: Statistical summarize of metrics to evaluate the performance of the WorldClim and Chelsa average temperature data with respect to the stations average temperature data.

\begin{tabular}{lcccccc}
\hline & \multicolumn{3}{c}{$\begin{array}{c}\text { Bias [\%] Annual } \\
\text { average } \\
\text { temperature }\end{array}$} & \multicolumn{2}{c}{$\begin{array}{c}\text { Pearson Corr. - Annual } \\
\text { Cycle }\end{array}$} \\
$\begin{array}{l}\text { Summarize of } \\
\text { metric }\end{array}$ & $\begin{array}{c}\text { World- } \\
\text { Clim }\end{array}$ & Chelsa & $\begin{array}{c}\text { World- } \\
\text { Clim }\end{array}$ & Chelsa & WorldClim & Chelsa \\
\hline $\begin{array}{l}\text { Number of sta- } \\
\text { tions }\end{array}$ & 11 & 11 & 11 & 11 & 11 & 11 \\
$\begin{array}{l}\text { Maximum } \\
\text { Minimum }\end{array}$ & 1.1 & 1.5 & $3.9 \%$ & $3.9 \%$ & 0.89 & 0.91 \\
Absolute Mean & 0.2 & 0.3 & $-2.4 \%$ & $-5.3 \%$ & 0.38 & 0.41 \\
& 0.5 & 1 & $2.0 \%$ & $3.9 \%$ & 0.72 & 0.73 \\
\hline
\end{tabular}


In general, WorldClim and Chelsa present a very similar behavior with respect to precipitation observations, with average percentage bias of 20 and $23 \%$, respectively, while the Pearson correlation coefficient of Chelsa is slightly better with an average value of 0.96 compared with 0.89 of WorldClim. Regarding the RMSE, Chelsa shows a slightly lower value, with an average of $59 \mathrm{~mm} / \mathrm{month}$, while WorldClim shows an average of $64 \mathrm{~mm} / \mathrm{month}$.

Regarding average temperature, as evidenced in the graphical analysis, Chelsa shows lower performance of magnitude representation than WorldClim, this is reflected in a greater percentage bias (3.9\% average for Chelsa versus $2.0 \%$ average for WorldClim) and at a higher RMSE $\left(1.0^{\circ} \mathrm{C}\right.$ average for Chelsa versus $0.5^{\circ} \mathrm{C}$ average for WorldClim).

\subsection{Spatial distribution of annual total precipitation and average annual temperature}

According to the representativeness analysis, both WorldClim and Chelsa represent well the annual average behavior of rainfall in the stations of the study area, therefore, either of the two datasets could be applied as an external drift for the interpolation of the annual precipitation data. Stochastic interpolation was applied using the kriging with external drift (KED) defined and programmed in HidroSIG Java software [10], [18], for which annual precipitation data was used from 37 of the 41 stations in the study area, and the gridded rainfall data of WorldClim and Chelsa were defined as external drifts of interpolation to improve the spatial tendency. The results obtained are shown in Fig. 4.

We find that both spatial behavior and magnitude of precipitation in the study area are very similar between maps interpolated with WorldClim drift and Chelsa drift, validating their similarity in precipitation representativeness as previously mentioned. The precipitation maps show a variation wide range, between a minimum of $1,331 \mathrm{~mm} /$ year up to a maximum of $5,201 \mathrm{~mm} / \mathrm{year}$, additionally this range is represented with a marked and defined spatial variability, the lowest rainfall occurs towards the northern of analysis domain, while the

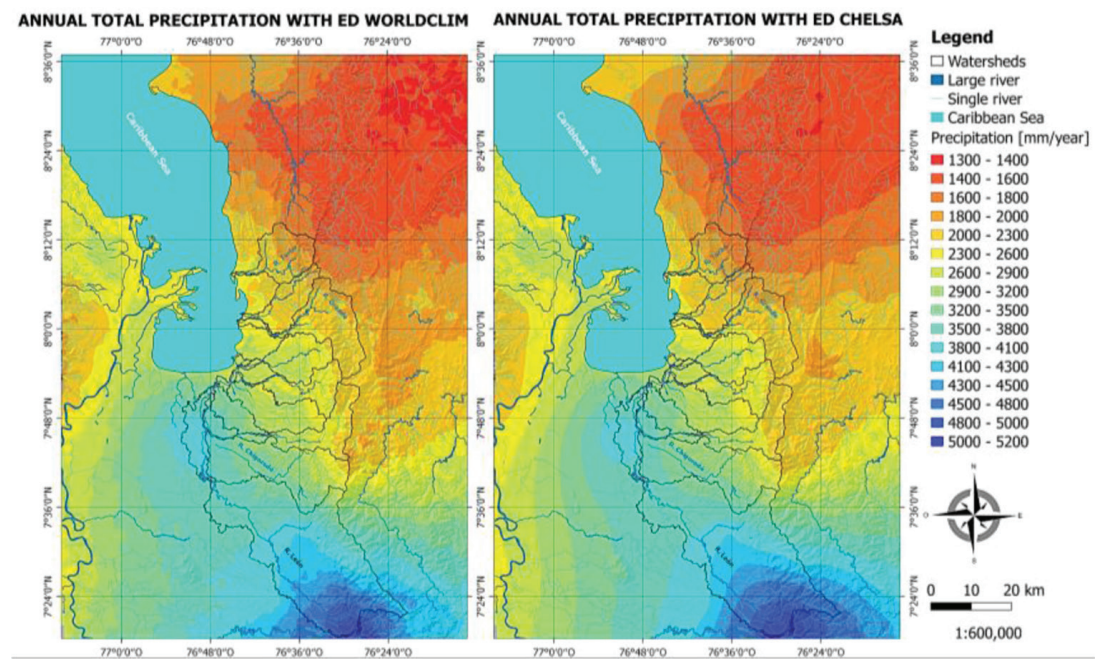

Figure 4: Spatial distribution of annual total precipitation for the study area: by KED interpolation with WorldClim as drift (left) and with Chelsa as drift (right). 
highest rainfall occurs towards the southern of the analysis domain, coinciding with the upper part of the Abibe mountain range, where there is high rainfall and the source of León River.

Specifically, for the watersheds of interest, there is a rainfall gradient in a south - north direction going from rainfall between 4,500 mm/year in the upper part the León River basin to rainfall between $1,500 \mathrm{~mm} /$ year in the Turbo river watershed.

Regarding average temperature, it's clear that the WorldClim data shows a better performance than Chelsa data, therefore, the WorldClim data has been considered for the construction of the annual average temperature field in the study area which it's presented in Fig. 5, accompanied by the annual average temperature map estimated by the Cenicafé method for the Atlantic region of Colombia, that is directly related to the terrain elevation [14]. We observe that both maps have a very similar spatial behavior and magnitudes, therefore, the use of the WorldClim average annual temperature map is validated.

\subsection{Spatial distribution of annual total actual evapotranspiration}

To complete the elements to apply the long-term water balance equation in the study area, the spatial estimation of annual actual evapotranspiration (AET) is required, for which the enunciated methods in the section 3.5 are applied. For the spatial application of the expressions we have used the precipitation resulting from the KED with WorldClim as external drift, to be consistent with the data source of the subsequent variables; annual and monthly average temperature from WorldClim and monthly solar radiation from WorldClim. The results obtained by the four methods are shown in Fig. 6.

We find that the Thornthwaite and Turc methods estimate the highest values of AET, between 1,900 and 2,200 mm/year and between 1,800 and 2,100 mm/year respectively, while the Cenicafé method estimates the lowest values of AET and Hargreaves method represents intermediate conditions. The spatial distribution of evapotranspiration (AET) is propitiated by two main factor that favour the occurrence of this process: The available water due to the greater occurrence of precipitation and the available energy related to solar radiation and temperature.
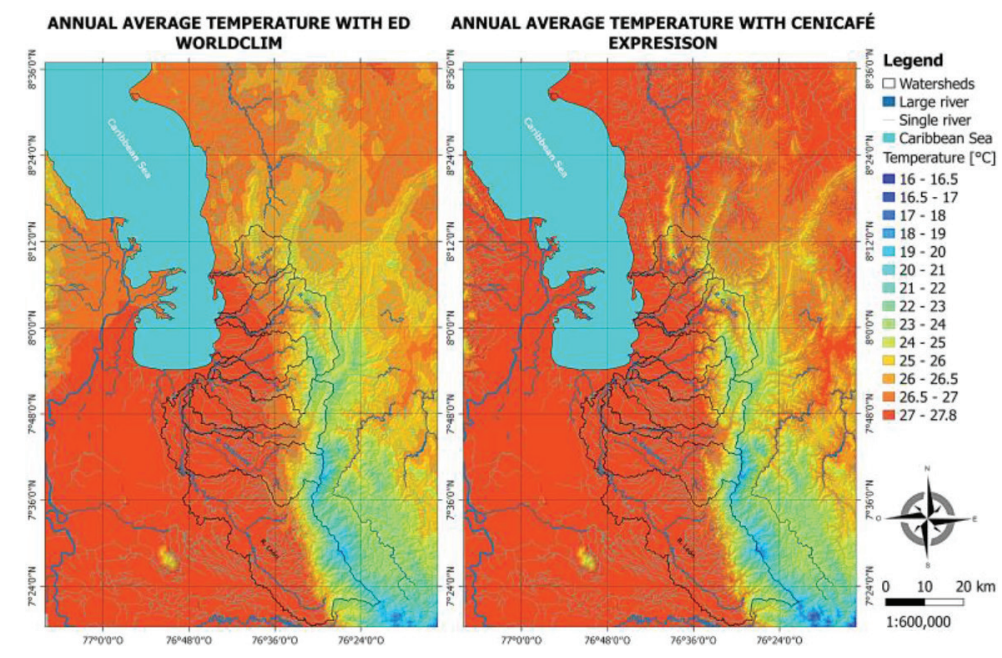

Figure 5: Spatial distribution of annual average temperature for the study area: by KED interpolation with WorldClim as drift (left) and by Cenicafé method (right). 


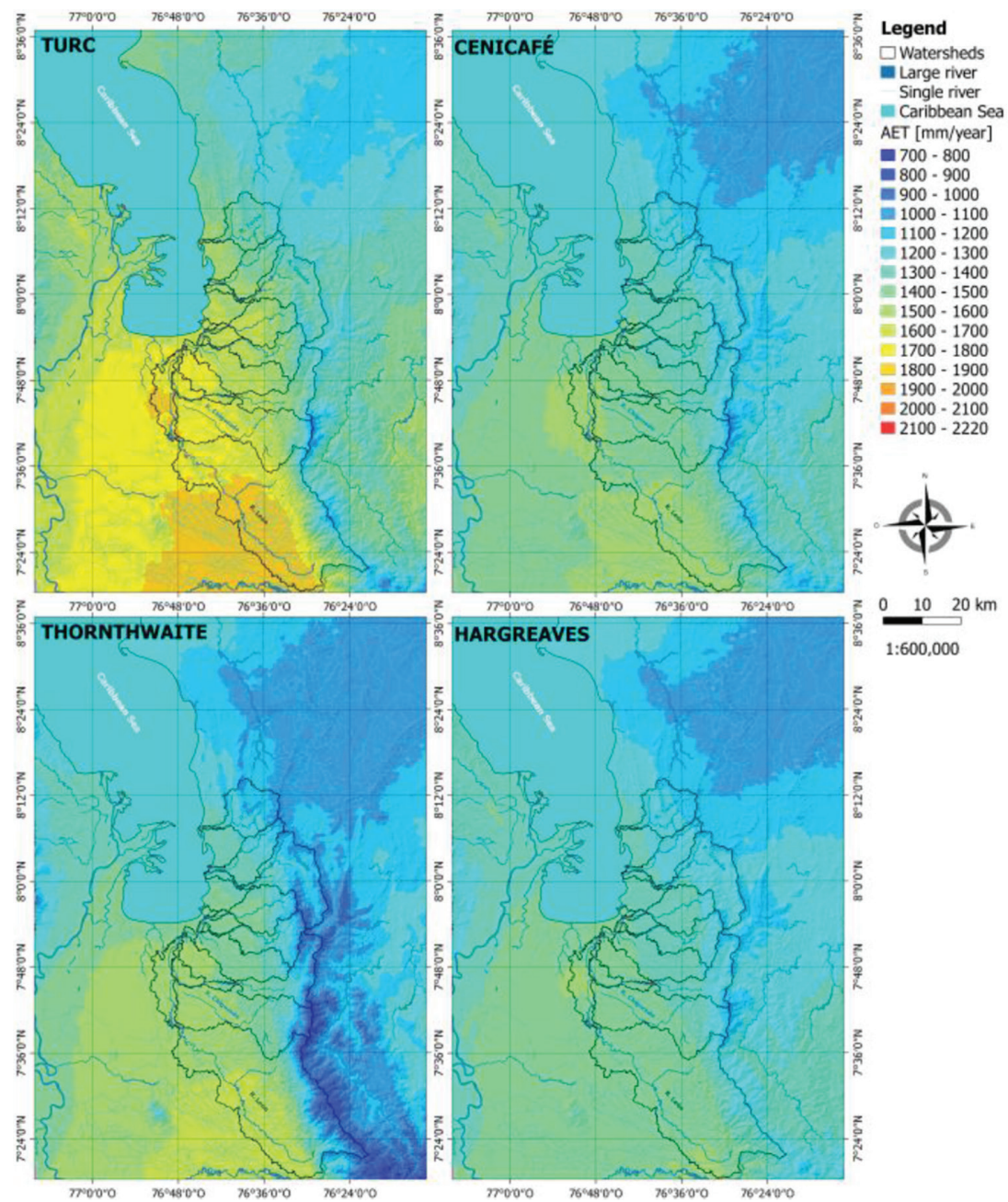

Figure 6: Spatial distribution of annual total actual evapotranspiration (AET) for the study area by four different methods.

\subsection{Long-term water balance in the watershed of the study area}

With the annual variables of precipitation and actual evapotranspiration (four scenarios) spatially estimated for long-term average conditions, we have applied the long-term surface water balance equation (eqn (1)), considering the drainage network and flow directions, obtained as the first step for the definition of the watersheds of interest (modelling static stage), in such a way, the runoff flows resulting from water balance are transited to the main streams.

$$
\{\bar{R}\}=\{\bar{P}\}-\{\bar{E}\} \text {. for the terrestrial surface. }
$$

where $\{\bar{R}\}=$ temporal and spatial average total runoff; $\{\bar{P}\}=$ temporal and spatial average precipitation; $\{\bar{E}\}=$ temporal and spatial average evapotranspiration. 
Table 4: Results of the estimated average streamflows for the main river in the study area by long-term water balance and different evapotranspiration methods.

\begin{tabular}{|c|c|c|c|c|c|c|}
\hline \multirow[b]{2}{*}{ Station } & \multirow[b]{2}{*}{ River } & \multirow{2}{*}{$\begin{array}{c}\text { Observed } \\
\text { average } \\
\text { streamflows } \\
{\left[\mathrm{m}^{3} / \mathrm{s}\right]}\end{array}$} & \multicolumn{4}{|c|}{ Estimated average streamflows $\left[\mathrm{m}^{3} / \mathrm{s}\right]$} \\
\hline & & & Turc & Cenicafé & Hargreaves & Tornthwaite \\
\hline Apartado & Apartado & 5.3 & 2.7 & 3.2 & 3.2 & 3.4 \\
\hline Barranquillita & Leon & 74.4 & 55.3 & 60.8 & 61.3 & 61.3 \\
\hline Carepa & Carepa & 6.1 & 4.8 & 5.6 & 5.7 & 6 \\
\hline Cerrazon La & Chigorodo & 5.6 & 2.6 & 2.9 & 3 & 3.2 \\
\hline Chigorodo & Chigorodo & 13.8 & 8.5 & 9.8 & 9.9 & 10.1 \\
\hline Currulao & Currulao & 7.2 & 5.6 & 6.6 & 6.6 & 7.3 \\
\hline Dos El & Turbo & 3.5 & 2.8 & 3.5 & 3.5 & 3.7 \\
\hline Pte Carretera & Zungo & 2.3 & 1.8 & 2.1 & 2.2 & 2.2 \\
\hline Riogrande & Grande & 2.5 & 1.8 & 2.1 & 2.1 & 2.2 \\
\hline Tres El & Guadualito & 2.2 & 1.6 & 2 & 2.1 & 2.1 \\
\hline Victoria La & Vijagual & 1.8 & 0.9 & 1.1 & 1.1 & 1.1 \\
\hline \multirow[t]{3}{*}{ Villarteaga } & Leon & 17.5 & 14.1 & 15.2 & 15.3 & 15.6 \\
\hline & $\mathrm{RMSE}\left[\mathrm{m}^{3} / \mathrm{s}\right]$ & & 5.97 & 4.29 & 4.14 & 4.07 \\
\hline & $\mathrm{R}^{2}$ coefficient & & 0.997 & 0.9971 & 0.9972 & 0.9969 \\
\hline
\end{tabular}

The long-term water balance is applied with the support of the HidroSIG and MapWindow software for each AET estimation method. The results of average streamflows estimated in the available hydrological stations are shown in Table 4, as well as the statistical evaluation of each estimation method, defined by RMSE and adjustment coefficient $\mathrm{R}^{2}$ between observed an estimated data.

We find that the average streamflow obtained from long-term water balance for all evapotranspiration methods, underestimate the average streamflows observed of the main stream of the study area, this underestimation is greater in the balance made with the Turc method,
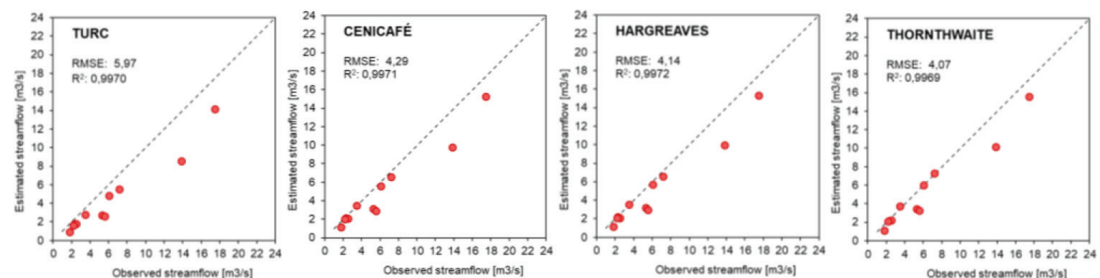

Figure 7: Comparison of observed average streamflows (hydrological stations) and estimated average streamflows (obtained from long-term water balance) for different evapotranspiration estimation methods. 
showing the highest RMSE, while the lowest underestimations that correspond to the lowest RMSE are shown by the balances made with the Hargreaves and Thornthwaite methods. This behavior of estimations also can be seen in Fig. 7, where it is observed that in general the water balance method is a good approximation for average streamflows estimation, with adjustment coefficient $\mathrm{R}^{2}$ around 0.99 .

\section{CONCLUSSIONS}

The high-resolution gridded climate data available in WorldClim and Chelsa global datasets suggest valuable information for the long-term spatial distribution estimates of hydroclimatological variables such as precipitation, average temperature and evapotranspiration.

For the Urabá Banana Axis region (Colombia), the gridded precipitation data of WorldClim and Chelsa showed a very good performance with respect the observed precipitation data in the stations (IDEAM stations), being useful to be used as auxiliary variables (particularly as external drift) in spatial interpolations. Regarding average temperature, Chelsa gridded average temperature data showed a low performance with respect to the magnitude of the observed average temperature data in the stations (IDEAM stations), while the WorldClim gridded data of this same variable showed a good performance with respect to the observed data, we concluded that the WorldClim gridded temperature data is more suitable to be used in spatial estimates for this region.

The availability of high-resolution spatial gridded climate data such as temperature, solar radiation, wind speed and vapour pressure in the WorldClim and Chelsa datasets, allow the consideration of more actual evapotranspiration estimation methods based on these variables.

The actual evapotranspiration estimates by the Thornthwaite and Hargreaves methods for the Urabá Banana Axis region (Colombia) allow to obtain a better representation of the longterm average streamflows in the main streams, in addition, these methods allow to consider the seasonal variability (annual cycle) of variables directly related to the evapotranspiration process, such as solar radiation and temperature.

\section{ACKNOWLEDGEMENTS}

A special thanks is extended to the engineer Kelly Dulce for her collaboration in the processing of time series of hydrometeorological variables in the area, and to the IDEAM Institute for the supply of meteorological information. This study was developed within the framework of Evidence4Policy cooperation project between Universidad de Antioquia and UNESCO - IHE.

\section{REFERENCES}

[1] Shuttleworth, W.J., Terrestrial Hydrometeorology, John Wiley and Sons, 2012. https:// doi.org/10.1002/9781119951933

[2] Caicedo Carrascal, F.M., Asimilación de precipitación estimada por imágenes de satélite en modelos hidrológicos aglutinados y distribuidos, caso de estudio afluencias al Embalse de Betania (Huila, Colombia), Pontificia Universidad Javeriana, 2008.

[3] Park, N., Kyriakidis, P.C. \& Hong, S., Geostatistical integration of coarse resolution satellite precipitation products and rain gauge data to map precipitation at fine spatial resolutions. Remote Sensing, 9(3), p. 255, 2017.

[4] Fick, S.E. \& Hijmans, R.J., WorldClim 2: new 1-km spatial resolution climate surfaces for global land areas. International Journal of Climatology [Internet], 37(12), pp. 4302-4315, May 15, 2017, available from https://doi.org/10.1002/joc.5086, 2017. 
[5] Karger, D.N., Conrad, O., Böhner, J., Kawohl, T., Kreft, H., Soria-Auza, R.W. \& Kessler, M., Climatologies at high resolution for the earth's land surface areas. Scientific Data [Internet], 4, pp. 1-20, 2017, available from: http://dx.doi.org/10.1038/sdata.2017.122

[6] van Soesbergen, A. \& Mulligan, M., Uncertainty in data for hydrological ecosystem services modelling: Potential implications for estimating services and beneficiaries for the CAZ Madagascar. Ecosystem Services [Internet], 33, pp. 175-186. To be published, available from: https://doi.org/10.1016/j.ecoser.2018.08.005

[7] Malekian, A. \& Ghasemi, E., Assessing the Applicability of CHELSA data for Monthly Precipitation. Presented at Terrestrial System Research: Monitoring, Prediction and High Performance Computing, Bonn, Germany, 2018.

[8] Gobernación de Antioquia. \& Fundación EPM. Antioquia un territorio para proteger: estado del recurso hídrico en Antioquia, Medellín, 2018.

[9] DAAC, A., PALSAR_Radiometric_Terrain_Corrected_high_res, Includes Material () JAXA/METI 2007. Dataset Online: https://vertex.daac.asf.alaska.edu/, 2015 (accessed through ASF DAAC 11 November 2015). https://doi.org/10.5067/Z97HFCNKR6VA

[10] Álvarez, O., Cuantificación de la incertidumbre en la estimación de Campos Hidrológicos. Aplicación al Balance Hídrico de Largo Plazo. Universidad Nacional de Colombia; 2007.

[11] Amaya, G., Tamayo, C.R., Vélez, M.V., Vélez, J.I. \& Álvarez, O.D., Modeling the hydrological behavior of three catchments in the Uraba Region - Colombia. Avances en Recursos Hidráulicos, 19, pp. 21-38, 2009.

[12] Nerini, D., Zulkafli, Z., Wang, L.P., Onof, C., Buytaert, W., Lavado-Casimiro, W. \& Guyot, J.L., A comparative analysis of TRMM - rain gauge data merging techniques at the daily time scale for distributed rainfall - runoff modeling applications. Journal of Hydrometeorology, 16(5), pp. 2153-68, 2015.

[13] Budyko, M.I., Climate and Life, Academic Press: New York, NY, 1974.

[14] Barco, O.J. \& Cuartas, A., Estimación de la Evaporación en Colombia. Universidad Nacional de Colombia sede Medellín, 1998.

[15] Turc, L., Water requirements assessment of irrigation, potential evapotranspiration: Simplified and updated climatic formula. Annales Agronomiques, 12, pp. 13-49, 1961.

[16] Thornthwaite, C.W., An approach toward a rationalclassification of climate. Geographical Review 38, pp. 55-94, 1948.

[17] Hargreaves, G.L. \& Samani, Z.A., Estimating potential evapotranspiration. Tech. Note. Journal of the irrigation and Drainage Division 108(3), pp. 225-230, 1985.

[18] Poveda, G., Mesa, O., Vélez, J., Mantilla, R., Ramírez, J.M., Hernández, O. \& Borja, A.U., HidroSIG: An interactive digital atlas of Colombia's hydro-climatology. Journal of Hydroinformatics 9, pp. 145-56, 2006. 